\title{
The evaluation of peer education workshops efficacy on knowledge of non medical students about HIV/AIDS, Bushehr, South of Iran
}

\author{
Hesam_oddin Maneshi*, Ismaeil Asaadi \\ From $16^{\text {th }}$ International Symposium on HIV and Emerging Infectious Diseases \\ Marseille, France. 24-26 March 2010
}

\section{Background}

Some researches have shown that lack of information in high-risk communities, especially among young people about ways of transmission and protection of HIV/AIDS increase risk of disease. Different strategies regarding the risk of AIDS awareness have been used up to now. The present study is done to evaluate peer education workshops efficacy on knowledge of non medical student (of Khalij-e-fars university and Bushehr payam-enour university) about HIV/AIDS.

\section{Methods}

In this interventional study, rate of awareness of 144 students participated in peer education HIV/AIDS workshop in 2009 as a pre-test and post test questions in the form of a questionnaire 7 is assessed. Data are analyzed using SPSS version 13.0 and student T Test. $\mathrm{P}<0.05$ indicated a statistically significant difference between groups.

\section{Results}

144 non-medical students from two Persian Gulf University (63) and Bushehr payame noor University (81) participate in this study. There is a significant difference between rate of correct responses of all students in pre test and post test questions, test 1 ( $\mathrm{P}$ value $<0.001$ ), test $4(\mathrm{P}$ value $=0.001)$, test $5(\mathrm{P}$ value $<0.001)$ and test 6 $(\mathrm{P}$ value $=0.004)$. The mean of pre test score was 4.73 with standard deviation 1.10 and the mean of post test score was 5.31 with standard deviation 0.94. This increase in terms of knowledge is statistically significant $(P$ value $<0.001)$.

\footnotetext{
* Correspondence: h_maneshi@yahoo.com

Bushehr University of Medical Sciences - Student's Research Committee, Bushehr, Iran, Islamic Republic of
}

\section{Discussion}

In this study students awareness about HIV/AIDS after workshops teached by the peer education group had a significant increase and regards to effectiveness of this method, students' cooperation and financial benefits of such trainings using this method can have a large share in student education.

Published: 11 May 2010

doi:10.1186/1742-4690-7-S1-P136

Cite this article as: Maneshi and Asaadi: The evaluation of peer education workshops efficacy on knowledge of non medical students about HIV/AIDS, Bushehr, South of Iran. Retrovirology 2010 7(Suppl 1): P136.
Submit your next manuscript to BioMed Central and take full advantage of:

- Convenient online submission

- Thorough peer review

- No space constraints or color figure charges

- Immediate publication on acceptance

- Inclusion in PubMed, CAS, Scopus and Google Scholar

- Research which is freely available for redistribution
Biomed Central 